\title{
Když dva dělají totéž: srovnávací tradiční rétorická analýza
}

\author{
Marek Picha \\ Filozofická fakulta \\ Masarykova univerzita \\ Arna Nováka 1, 60200 Brno \\ picha@phil.muni.cz
}

Text porovnává přesvědčovací strategie využité ve velmi podobných politicky angažovaných videoklipech The Great Schlep a Přemluv bábu. Ukazuje, že přestože se klip Přemluv bábu od své americké předlohy zásadně neliší v obecné struktuře, deklarovaném cíli či motivické výbavě, $v$ jiných persvazivně významných ohledech se původnímu klipu vzdaluje. Rozdíly jsou patrné zejména v odlišné konstrukci publika, $v$ jiném situování mluvčích a v topickém výběru vyjádřeném jinými stylistickými prostředky.

Klíčová slova: rétorika, neoaristotelismus, Přemluv bábu, The Great Schlep, srovnání

\section{Úvod}

Čtyřminutový videoklip Přemluv bábu ${ }^{1}$ vzbudil na jaře roku 2010 před blížícími se parlamentními volbami rozporuplné reakce. Publikum bylo výrazně rozdělené: jedni oceňovali humor, př́močarost sdělení a jeho cíl, druzí označovali klip za vulgární, urážlivý a nepatřičně zjednodušující. ${ }^{2}$ Velmi blízkou předlohou tohoto klipu je The Great Schlep ${ }^{3}$, video

1 Issová, Mádl \& Zelenka (2010). Odkaz na video a přepis celého textu je k dispozici v editorialu tohoto čísla časopisu na s. 7-9.

2 Viz například Berger, Piroch \& Bumba (2010).

3 Silverman (2008). 
natočené v roce 2008 ve prospěch prezidentské kandidatury Baracka Obamy. The Great Schlep, byt’ je stejně politicky vyhraněný jako Přemluv bábu, byl přjiat vřeleji. ${ }^{4}$

Oba klipy neformálním jazykem oslovují mladé publikum. Relativně známí mluvčí v nich předkládají důvody, proč by mladí lidé měli podniknout cestu za svými staršími rodinnými příslušníky. Prezentují příčiny stávající politické situace a ukazují způsoby, jak seniory přimět ke změně jejich politické volby. Klipy využívají stejně zarámované statické scény, výrazného hudebního podkresu a podobného obrazového doprovodu. Přestože mají tolik společných rysů, že lze Přemluv bábu považovat za lokalizaci ${ }^{5}$ The Great Schlep, najdeme v těchto klipech odlišné přesvědčovací postupy vyjádřené rozdílnými výrazovými prostředky. Cílem tohoto textu je popsat dílčí strategické volby, jež autoři klipů učinili ve snaze přimět své publikum k politicky motivovanému jednání. Mým hlavním analytickým nástrojem bude srovnání některých persvazivně významných rysů obou klipů, přičemž výběr těchto rysů bude určen rámcem tzv. tradiční rétorické kritiky.

\section{Tradiční rétorická kritika}

Herbert A. Wichelns v textu The Literary Criticism of Oratory formuloval postupy a cíle rétorické kritiky, jež se měla stát svébytným způsobem diskurzivního zkoumání. ${ }^{6}$ Wichelns postavil rétorickou kritiku do kontrastu s literární kritikou: zatímco literární kritice jde podle Wichelnse o postižení nadčasové hodnoty a estetické kvality díla, rétorická kritika

4 The Great Schlep obdržel Webby Award 2009 za nejlepší politické video, dosáhl 342 milionů impresí, k programu se přihlásilo 25 ooo lidí. Na portálu YouTube má dnes Přemluv bábu srovnatelné množství kladných a záporných hodnocení, přibližně 2500 kladných a 2400 záporných, naproti tomu The Great Schlep má přibližně 7500 kladných a 2000 záporných hodnocení. Tato metrika úspěšnosti klipu je samožrejmě extrémně nepřesná a rozdílné absolutní počty hlasů o ničem nevypovídají, avšak odlišné poměry kladných a záporných hodnocení mohou signalizovat odlišné přijetí klipů veřejností.

5 Národní galerie reklamy hovoří o „parafrázi slavného spotu Sarah Silverman“. Tvůrci souvislost svého klipu s The Great Schlep nijak rozsáhleji nekomentovali, jeho režisér Petr Zelenka však v rozhovoru pro Českou televizi zmínil, že se „inspirovali americkejma vzorama“, že se k souvislosti s klipem Sarah Silvermanové „hlásil od začátku“ a že „ty nejkontroverznější věci jsou [...] vlastně př́mo od ní převzatý“, Srovnej ČT24 (2010, 1:30).

6 Srovnej Wichelns (1925). 
má zkoumat aktuální vliv řeči na aktuální publikum. Zajímá ji účinnost řeči, přesněji její přesvědčivost.

Wichelnsův text byl průkopnický nejen tím, že poukázal na nový předmět zkoumání, ale především proto, že nabídl obecný plán, jak tento předmět pojednat. Edwin Black zmiňuje Arnoldovu studii ${ }^{7}$ o americké rétorice první poloviny 20. století, podle níž před rokem 1920 neexistuje prakticky žádná systematická rétorická kritika. ${ }^{8}$ Teprve Wichelnsův program lze považovat za první pokus o metodické uchopení přesvědčovacího účinku řeči. ${ }^{9}$ Klíčový je v tomto směru následující odstavec Wichelnsova textu:

„Rétorická kritika je nutně analytická. Způsob rétorického zkoumání zahrnuje jakožto formující okolnost osobnost řečníka; zahrnuje také jeho veřejný obraz - ne to, čím byl, nýbrž za jakého byl považován. Nezbytný je popis jeho publika a také ústředních myšlenek, $\mathrm{s}$ nimiž se řečník obracel $\mathrm{k}$ posluchačům - témata, motivy, na něž se odvolával, povaha důkazů, jež nabízel. Ty odhalí jeho vlastní představu o povaze publika a také řečníkův náhled na diskutované otázky. Pozornost je rovněž třeba věnovat vztahu mezi dochovaným textem a tím, co bylo skutečně proneseno: $\mathrm{v}$ př́ipadě, že tyto změny známe, lze zohlednit přizpůsobení textu dvěma publikům - tomu, které ho slyšelo, a tomu, které ho četlo. Rétorická kritika také nemůže vynechat řečníkův způsob sestavení řeči, způsob vyjadřování, přípravu projevu a jeho konkrétní přednes; ačkoli poslední dvě položky jsou patrně méně důležité. Pozornost si zaslouží ,styl - ve významu dikce a plynulosti vět - avšak pouze jen jako jeden z mnoha způsobů, jimiž si mluvčí dláždí cestu do myslí posluchačů. Konečně také nelze pomíjet vliv diskurzu na bezprostřední

7 Srovnej Arnold (1959).

8 Srovnej Black (1965, s. 18-19).

9 „[D]oslova vytvořil moderní disciplínu rétorické kritiky.“ (Klyn 1968, s. 154); ,[Tento esej] určil vzor a směr rétorické kritiky po více než čtvrtstoletí a měl větší a setrvalejší vliv na vývoj bádání o rétorice a veřejných projevech, než kterékoli jiné dílo publikované v tomto století." (Bryant 1958, s. 5). 
posluchače, at’ už ve formě přímých svědectví nebo ze záznamů. A neustále je nezbytné chápat mluvčího jako veřejnou osobu, která působí na své současníky silou řeči."

Wichelns buduje rétorickou kritiku jako popis přesvědčovací komunikace mezi mluvčím a publikem doplněný o hodnocení výsledku daného přesvědčování. Rétorický projev není primárně expresivní, jeho cílem je ovlivnění posluchače, a je tak výsledkem strategické volby prostředků přizpo̊sobených cíli. Při rétorické kritice má pak jít o explikaci těchto prostředků a zvážení, zda se jejich prostřednictvím mluvčímu podařilo u publika „změnit chápání skutečností"11.

Ve svém textu Wichelns podal programový výčet hledisek, jimž se má rétorická kritika věnovat (povaha a veřejný obraz mluvčího, publikum, hlavní myšlenky řeči, její motivická výstavba, podoba předložených důkazů, názory mluvčího na povahu publika, struktura řeči, způsoby vyjadřování, metoda přípravy, přednes řeči a její krátkodobý a dlouhodobý účinek), ovšem nenabídl konkrétnější postup, jak tato hlediska pojednat. Rétoričtí kritikové se proto při hledání dílčích metod obrátili k antické tradici, zejména $\mathrm{k}$ Aristotelově Rétorice a $\mathrm{k}$ textům významných latinských řečníků. Tyto klasické texty vznikly původně jako příručky, jako soubor doporučení a maxim, jež měly vést $\mathrm{k}$ lepší a přesvědčivější řeči, badatelé je ovšem uchopili jako metodologická východiska pro analýzu rétorických artefaktů. Tradiční rétorická kritika, někdy též označovaná jako klasická či neoaristotelská kritika, vytěžila z těchto antických zdrojů jen některé základní přístupy; ${ }^{12}$ určité formalizace se tento přístup dočkal především v knize Lestera Thonssena a A. Craig Bairda Speech Critici$s m,{ }^{13}$ kde autoři nabídli strukturovaný soubor analytických hledisek, jež lze při tradiční rétorické kritice uplatňovat samostatně či v kombinaci:

1. konstituenty řečové situace: mluvčí, publikum, téma, okolnosti

10 Wichelns (1925, s. 209-210).

11 Hill (2009, s. 39).

12 „Neoaristotelici mají nejspíš málo společného s Aristotelem kromě několika opakujících se diskusních témat a vágně příbuzného náhledu na rétorický diskurz; ale i tak platí, že tento náhled může posloužit k vymezení neoaristotelismu." (Black 1965, s. 33).

13 Za modelové ilustrace tohoto př́istupu jsou považovány eseje v Nichols (1955). 
2. řečníkovy povinnosti a cíle: účel řeči, řečníkova kvalifikace

3. typy řeči: deliberativní, soudní, slavnostní, náboženské

4. tradiční části umění řečnického: invence, dispozice, elokuce, zapamatování, přednes

5. účinek řeči: bezprostřední, zprostředkovaný ${ }^{14}$

Black popisuje tradiční metodu rétorické kritiky následovně:

„Primárními a určujícími myšlenkami neoaristotelismu, jež se opakují v kritických esejích této školy, jsou klasifikace rétorických diskurzo̊ na forenzní, deliberativní a epideiktické; klasifikace ,důkazư‘ či ,způsobů přesvědčování na logické, patetické a etické ${ }^{15}$; hodnocení diskurzu v kategoriích vyhledání důvodů, sestavení řeči, přednesu a stylu; a hodnocení rétorického diskurzu ve smyslu účinku na bezprostřední publikum." ${ }^{16}$

Hill charakterizuje obvyklý postup tradiční kritiky stručněji: představení kontextu, představení publika, popis zdroje sdělení, analýza sdělení, hodnocení diskurzu. ${ }^{17}$ Fossová popisuje neoaristotelský přístup dokonce ještě úsporněji jako třístupňovou analýzu, ve které postupujeme od rekonstrukce kontextu přes aplikaci pěti kánonů klasické rétoriky ke zhodnocení účinku artefaktu na publikum. ${ }^{18}$

Zhruba od sedmdesátých let dvacátého století přestal být neoaristotelismus prominentním přístupem rétorické kritiky. ${ }^{19}$ Sílící odmítavé hlasy

14 Srovnej Thonssen \& Baird (1948, s. 290-293).

15 Aristotelské termíny pathos a ethos bývají do současné češtiny přeloženy nejčastěji jako patos a étos. O přesvědčování patosem můžeme bez potíží psát jako o patetickém přesvědčování, budeme-li však psát o přesvědčování étosem jako o etickém přesvědčovaní, může to vést k nedorozumění. Čtenář totiž snadno zamění etické přesvědčování ve smyslu přesvědčování étosem za etické přesvědčování ve smyslu přesvědčování morálními důvody. Stejné nebezpečí hrozí mimochodem i v angličtině, kde se proto někteři autoři rozhodli rozlišovat mezi ethotical persuasion a ethical persuasion. $Z$ různých návrhů, jak psát shodným př́ivlastkem o přesvědčování étosem (ethické?, étické?, ethotické?), nakonec volím variantu etické přesvědčování. Adjektivum etické tedy v tomto textu vždy označuje týkající se étosu, nikdy morální.

16 Black (1965, s. 31).

17 Srovnej Hill (2009, s. 40).

18 Srovnej Foss (1989, s. 32).

19 Srovnej Stewart (1973, s. 4). 
poukazovaly především na omezenost daného způsobu zkoumání: důraz na objektivní popis rétorického artefaktu a jeho okamžitého účinku, který „ignoruje všechna hodnocení kromě těch, jež se týkají schopnosti promluvy vybudit zamýšlenou reakci bezprostředního publika“, ${ }^{20}$ je chápán jako zbytečně restriktivní a krátkozraký. Tradiční analýza je vnímána jako zastaralá, nebot je budovaná pomocí archaických kategorií klasické rétoriky, jež jsou navíc uchopeny jako kritické prostředky, nikoli jako praktická doporučení. ${ }^{21}$

Přes tyto výhrady považuji tradiční rétorickou kritiku za přijatelný ${ }^{22}$ nástroj dílčí srovnávací analýzy. Nabízí jednoduchý, avšak poměrně jasný aparát k popisu struktury rétorických artefaktů, pojmová výbava klasické rétoriky umožňuje komentovat budování, styl i přednes srovnávaných řečí. Ve srovnávací analýze klipů The Great Schlep a Přemluv bábu budu sledovat dva hlavní metodologické postuláty tradiční rétorické kritiky: (i) v souladu s Aristotelovou definicí rétoriky ${ }^{23}$ se budu soustředit na bezprostřední účinek těchto klipů, (ii) srovnání bude organizováno do dvou celků - expozice, ve které stručně popíši okolnosti řeči, mluvčí, povahu publika a strukturu klipů, a analýzy sdělení, kde srovnám přesvědčovací postupy a stylové prostředky obou klipů.

\section{Expozice}

Nově založená nezisková organizace Jewish Council for Education and Research se v září roku 2008 uvedla kampaní The Great Schlep (TGS), jejíž stěžejní částí byl videoklip podporující prezidentskou kandidaturu Baracka Obamy. Kampaň formovala tvưrčí dvojice Mik Moore a Ari Wallach, podílela se na ní reklamní agentura Droga5 a její tváří se stala americká komička Sarah Silvermanová. Kampaň zohledňovala dvě dílčí okolnosti. Zaprvé, voličskou zkušenost s prezidentskou volbou roku 2000, při které republikánský kandidát George W. Bush minimálním

20 Campbell (1972, s. 454).

21 Srovnej Ehninger (1965, s. 230).

22 Srovnej Hendrix (1968, s. 249), kde poukazuje na chybnou kritiku tradičního přístupu založenou na zobecněných aplikacích tohoto přístupu.

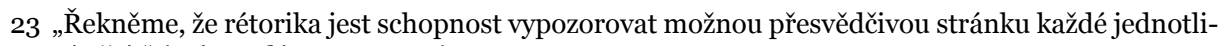
vé věci.“ (Aristotelés 2010, s. 26). 
rozdílem porazil demokratického protikandidáta Ala Gorea. Nejtěsnější rozdíl hlasů v dané volbě zaznamenal stát Florida (o,01 \%, 537 voličů); v americkém volebním systému však i takto těsný výsledek představoval zisk všech 25 volitelských hlasů států Florida, které se pak podílely na Bushově celkovém vítězství 271:267. Druhou významnou okolností je demografické rozložení obyvatel Floridy. Po New Yorku a Kalifornii je Florida třetím americkým státem s nejvyšší židovskou populací; statistiky uvádějí kolem 620000 př́slušníkủ židovského etnika, z nichž je zhruba půl milionu registrovaných voličů. ${ }^{24}$

Klip Přemluv bábu (PB) vznikl v druhé polovině dubna 2010, tedy měsíc před parlamentními volbami. Projekt inicioval a režisérsky vedl Petr Zelenka, ideovým tvůrcem byl Marek Prchal, tým pracoval pro bono a projekt neměl žádného zadavatele. I v této kampani hrála významnou roli voličská zkušenost. V roce 2008 proběhly volby do krajských zastupitelstev spojené s volbami do Senátu, jež skončily drtivým vítězstvím levicové ČSSD, která vedle toho, že zvítězila ve všech mimopražských krajích, získala i 23 z 27 senátních mandátů. Druhou formující okolností byly průzkumy zkoumající voličské preference od ledna do dubna 2010, které se shodovaly v dominanci ČSSD a předpovídaly pro ni přibližně $27 \%$ zisk. ${ }^{25}$ Třetí významnou okolností je volební geografie, respektive představa o rozvrstvení voličské základny vzhledem k regionu, vzdělání a věku. Typický volič levice je v té době líčen jako nanejvýš středoškolsky vzdělaný člověk stř̌edního věku žijící mimo velká města. Poslední okolností, která hraje roli při porozumění klipu, je skutečnost, že v roce 2010 se voleb zúčastnilo několik nově vytvořených stran a hnutí, předvolební průzkumy naznačovaly možný úspěch pravicové TOP o9 i levicové Strany práv občanů.

\section{Mluvčí}

V TGS oslovuje diváky osmatřicetiletá žena židovského původu, komička známá ostrým humorem a nevybíravými komentáři. $\mathrm{V}$ dané době byla Sarah Silvermanová na vrcholu popularity: její provokativní hudební

24 Srovnej Sheskin \& Dashefsky (2010, s. 14), případně Tate (2012).

25 Srovnej např. STEM (2010). 
číslo z ledna 2008 I’m $F^{* * * i n g ~ M a t t ~ D a m o n ~ z i ́ s k a l o ~ P r i m e t i m e ~ E m m y ~}$ Award za nejlepší původní hudbu a text, vedle dvou dalších nominací na Emmy Award byla v daném roce nominována i na cenu Writers Guild of America za scénár ke komediálnímu seriálu The Sarah Silverman Program, v předcházejícím roce moderovala předávání MTV Movie Awards.

PB má mluvčí dva. Vedle devětadvacetileté Marthy Issové hovoří v klipu třiadvacetiletý Jiří Mádl, v obou případech jde o veřejně známé herce, a to především díky účinkování ve filmech pro mladší diváky. ${ }^{26}$ Rozdělení rolí uvnitř dvojice není symetrické. Martha Issová je obrazem Silvermanové, zprostředkovává úvod i závěr klipu, je ohniskem pozornosti, je výrazněji oblečená a má větší verbální prostor než její mužský partner. Ten působí jako přizvaný host; Issová ho uvádí a představuje, on většinu času přitakává či ji drobně opravuje.

\section{Publikum}

Má-li rétorická kritika podle Thonssena a Bairda vhodně popsat způsoby, jimiž mluvčí směruje posluchače $\mathrm{k}$ přijetí svých myšlenek a cílů, neobejde se bez popisu publika. ${ }^{27}$ Autoři nabízejí následující výčet deskriptivních kategorií: (1) věk, (2) pohlaví, (3) znalost tématu, (4) politické, sociální, náboženské a další příslušnosti, (5) ekonomický status, (6) známý či předpokládaný postoj k tématu, (7) známé či předpokládané předsudky, (8) povolání, (9) veřejná zainteresovanost v tématu, (10) možná soukromá zainteresovanost $\mathrm{v}$ tématu, (11) nálada a tón dané události.

Oba klipy zcela otevřeně cílí na mladé publikum (1). Osloveni jsou politicky zodpovědní aktivní (6) mladí lidé, jejichž zapojení do předvolebního boje může mít rozhodující vliv na celkový výsledek voleb. Explicitním adresátem TGS je mladý Žid (4), jehož starší rodinní př́íslušníci žijí na Floridě; modelový posluchač je tedy vymezen průnikem věku, etnicity a adresy př́buzných. Adresátem PB je mladý člověk, jehož starší rodinní příslušníci žijí na venkově a etnicita nehraje roli. Publikum TGS je tak vymezeno úžeji než publikum PB, navíc pomocí vý-

26 Společně hráli ve filmu Děti noci (2008), Jiří Mádl si získal širokou popularitu především díky snímkům Snowboard'áci (2004) a Raftáci (2006).

27 Thonssen \& Baird (1948, s. 361-362). 
razné a kulturně bohaté vlastnosti, která umožňuje využít specifických přesvědčovacích postupů.

\section{Konstrukce publika}

Vedle publika, které je projevem hledáno, tj. mladých činorodých liberáli̊n, existuje i publikum, které je projevem konstruováno. V rámci projevu mohou být některé vlastnosti publika zdůrazněny, jiné potlačeny. Např́iklad oslovením či výslovným zařazením posluchačů do určité skupiny lze ovlivnit sebe-identifikaci posluchače a tím i jeho vnímavost k jistým přesvědčovacím postupům. TGS začíná takto:

„If you knew that visiting your grandparents could change the world, would you do it? Of course you would. You'd have to be a douche nozzle not to."

Tuto pasáž můžeme chápat jako konstrukci publika, a to dokonce hned dvojitou. Zaprvé, snaha o „změnu světa“ zdo̊razňuje morální kvalitu posluchače, jeho odpovědnost a vůli jednat. Tím, že je posluchač vylíčen jako přirozeně morální, je zároveň pobídnut, aby sám sebe vnímal především právě jako morálního aktéra a zároveň z této morální perspektivy hodnotil i další přesvědčování (6). Úvodní věta TGS tedy aktivuje v posluchači morální sebevědomí a konstruuje publikum, které bude lépe zohledňovat linii přesvědčování zdůrazňující dobré jednání. Není překážkou, že „změna světa“ může v dané formulaci znamenat vlastně cokoliv; na tomto místě jde o zvýraznění odpovědnosti posluchače vůči světu a o zdůraznění toho, že jeho morálně motivované jednání bude mít v dané kauze podstatný dopad.

Zadruhé, výraz ,douche nozzle‘ je slangový, dehonestující a silně vulgární. Použití takového označení v úvodu opět můžeme chápat jako snahu uvést posluchače do jistého rozpoložení, ve kterém budou zvolené přesvědčovací postupy účinné, tj. jako konstrukci publika. Hrubým výrazem v závěru úvodní pasáže se nejen zdůrazňuje otevřenost a přímočarost mluvčího, ale zároveň se tyto kvality očekávají i od posluchače. Konstruuje se publikum, které je ochotné vyslechnout přesvědčování 
formulované běžným jazykem, publikum, které neklade důraz na kulantnost vyjadřování, nýbrž na jeho srozumitelnost (11). Tato druhá konstrukce je navíc zdůrazněna v protikladu ke konstrukci první: publikum, které si je vědomo svého morálního charakteru a obecné odpovědnosti vůči světovému dobru, je vulgarismem transformováno do publika, které očekává konkrétní a srozumitelnou výzvu $\mathrm{k}$ morálně motivovanému jednání.

Konstrukce publika založená na jeho morálním sebevědomí beze změny platí i pro posluchače $\mathrm{PB}$, a to jednoduše z toho důvodu, že úvodní pasáž PB je téměř doslovnou citací úvodu TGS. Patrným rozdílem je vypípání posledního hrubého slova $\mathrm{v} P B$. Na jedné straně jde o postup odpovídající výše popsané strategii: přestože není publikum PB plně vystaveno kontrastu vznešené morální motivace a nízkého jazyka, jde i zde o publikum, které se má přirozeně bavit o vážných věcech - avšak $\mathrm{PB}$ toho záměru nedosahuje pomocí vulgarismu, nýbrž pomocí nespisovného jazyka (,týhle země‘, ,za nima', ,jasně, že jo', ,teda'). Výrazy obecné češtiny $\mathrm{v}$ kontrastu $\mathrm{s}$ důrazným přednesem a vznešeným tématem konstruují i zde publikum, které je ochotné odložit kulantní jazyk ve prospěch srozumitelné řeči o závažných tématech (11).

Na druhou stranu je ovšem vypípáním vulgarismu v PB konstruováno jiné publikum než v TGS. Nejprve si všimněme, že překrytí posledního slova je ornamentální v tom smyslu, že pro větu ,No jasně že jo. Teda pokud nejste úplně ...' neexistuje dostatečně vulgární adjektivum, jež by posluchač zvládl rychle do věty doplnit a zároveň by stálo za stylizovaný cenzorský zásah. ${ }^{28}$ Přesto je tento ornament součástí uváženého projevu, a lze tak předpokládat, že mu mluvčí připisuje nějakou rétorickou funkci. Přiznaná autocenzura nejspíš naznačuje, že mluvčí neusiluje o prvoplánově vulgární výpověd' a hrubý jazyk nemá být těžištěm klipu. Přesvědčování se bude odehrávat relativně slušnými výrazovými prostředky a bude cílit na racionálního posluchače (6). Tím, že PB okatě odmítá explicitní vulgarismus, vybízí publikum, aby hledělo spíše na předložené argumenty než na třeskutost slov. Úvodní vypípnutí tak můžeme chápat jako rétorický nástroj, kterým se stanovuje dialektický profil projevu:

28 Stačilo by nahradit slovo ,úplně slovem ,úplní, a vypípání by dávalo smysl, nebot’ vulgarit hodných cenzury lze pak již vymyslet nespočet. 
posluchač $\mathrm{PB}$ má očekávat spíše věcné, racionální přesvědčování vedené slušným jazykem, má předložené důvody z této perspektivy i hodnotit - na rozdíl od posluchače TGS, který má díky vyslovenému vulgarismu očekávat celou škálu přesvědčovacích prostř̌edků (např. dojetí, humor, šok, simplifikaci) a má pak tyto prostředky při hodnocení přesvědčivosti klipu chápat jako rovnocenné.

\section{Konstrukce vzdáleného publika}

Oba klipy jsou primárně výzvou k přesvědčovací aktivitě. Snaží se vybavit mladé lidi důvody, kterými by zapůsobili na staré. To znamená, že se v klipech zohledňují další posluchači, nepřímí adresáti přesvědčování, které budu nazývat vzdáleným publikem. Klícovými vlastnostmi vzdáleného publika TGS jsou stáří (1), židovství a bydliště na Floridě (4), ty jsou však ještě doplněny o subtilnější charakteristiky. Nejprve je využito srovnání prvotního a vzdáleného publika:

„Jew are the most liberal, scrappy, civil-rightsy people there are. Yes, that's true. But you are forgetting a whole large group of Jews that are not that way. And they go by several aliases: Nana, Papa, Zaide, Bubby, plain old Grandma and Grandpa. These are the people who vote in Florida." [0:35]

První věta je pokračováním konstrukce prvotního mladého publika, které by se mělo identifikovat s popisem Žida jakožto liberálního a ohleduplného občana. Následuje konstrukce vzdáleného publika, které tyto kladné vlastnosti postrádá. A protože se u něj uvedené občanské kvality nepředpokládají, přesvědčování na ně ani nebude cílit. Konstrukce vzdáleného publika zde tak omezuje výběr doporučených argumentů prvotního publika. Za pozornost stojí fakt, že tento nepřímý způsob připsání negativních vlastností vzdálenému publiku, tj. způsob, kdy se řekne, že starší Židé z Floridy postrádají jisté pozitivní vlastnosti, je jediným místem TGS, kde je vzdálené publikum peskováno.

Konstrukce vzdáleného publika pokračuje pomocí osobních pojmenování a ilustrací: zvoleny jsou pozitivně citově zabarvené vý- 
razy a pestré obrázky veselých, kultivovaně vypadajících seniorů. Podobně názorná konstrukce je patrná i v pasáži, kdy se srovnává ,an elderly jewish woman like Nana to a young black man' [1:25]. Typizovaná členka vzdáleného publika je usměvavá, zdravě a čile vypadající, nalíčená, ozdobena, její reakce směrem k mluvčí jsou vstř́ícné, často se směje (11). Vedle toho je ovšem schopná si připustit i nepř́ijemnou pravdu [2:17] a díky tomu je tak možné ji přesvědčováním přivést ke změně názoru (6). Z hlediska dalšího přesvědčování je klíčové, že se u vzdáleného publika TGS konstruuje silná identifikace s etnicitou. Klip je adresován mladým Židům, kteří mají oslovit starší rodinné příslušníky, pro něž je významné, že jsou Židé. Prezentováním ,starší Židovky“ (nikoli ,starší ženy') a zejména použitím jidišismů se konstruuje vzdálené publikum, které samo sebe vnímá jako starší a jako židovské. Na tyto rysy pak bude cílit další přesvědčování.

Vzdálené publikum v PB je zpočátku konstruováno podobně:

„Protože to jsou ty, který levici volej. To můžou bejt lidi z vaší rodiny. To může bejt vaše teta, váš strejda, vaše babička, váš děda. No. A většinou ty lidi bydlej na vesnici." [0:31]

Zde jsou klíčovými vlastnostmi stáří (1) a bydliště na venkově (4). PB se omezuje na strohé vyjádření, ve kterém nepokračuje v konstrukci primárního publika, ani neohraničuje prostor př́ípadných přesvědčovacích prostředků. Vzdálené publikum se stejně jako v TGS konstruuje pojmenováním a ilustrací, výrazy pro seniory jsou zde ale neutrální; výjimkou by mohla být zdrobnělina ,babička‘, avšak její použití je nejspíš vynucené tím, že v češtině prostě nemáme neutrální výraz, srovnej bába, babka vs. babi, babička. Zcela markantní je rozdíl v konstrukci vzdáleného publika na rovině ilustrací, kde se předkládají nelichotivé monotónní fotografie bezzubých zmatených stařen a starců, srovnej obrázek 1. 


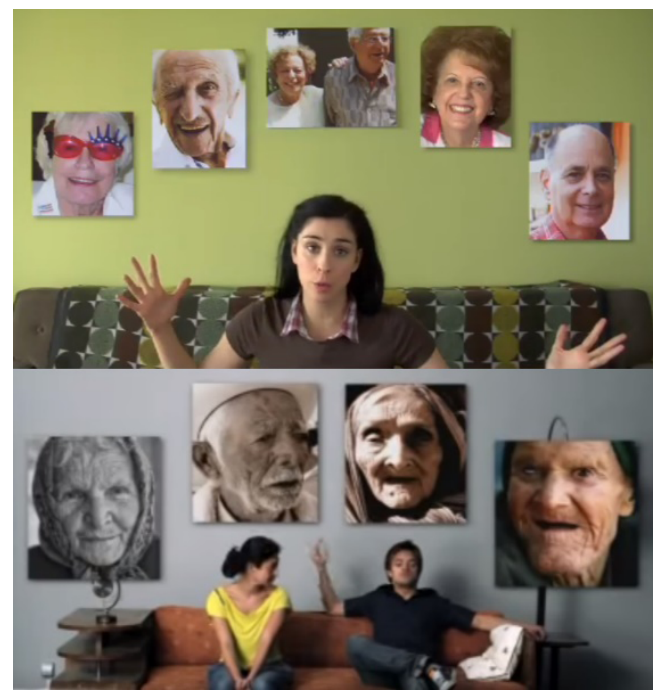

Obrázek 1

PB výslovně uvádí intelektuální nedostatky vzdáleného publika [o:56]. Staří lidé z vesnice jsou obětmi selektivní paměti (3), rozhodují se na základě nostalgie, nejsou schopni kritického odstupu, jejich intelektuální horizont je omezený (7), motivace přízemní (10). Jednoduše řečeno, vzdálené publikum je vylíčeno především jako hloupé, což je ještě zesíleno použitím obrazového doprovodu, kdy je spojení ,selektivní pamět doplněno ikonickou ilustrací př́liš drobného mozku.

\section{Struktura}

Z hlediska aristotelské typologie projevů jsou oba zkoumané klipy jasným prŕípadem deliberativní (poradní) řeči. Účelem takového projevu je povzbudit či odradit posluchače při rozhodování o veřejných věcech, jež se typicky týkají budoucnosti. ${ }^{29}$ Pro potřeby strukturálního rozboru lze řeč rozčlenit do několika funkčních celků v závislosti na sledované charakteristice; Thonssen a Baird uvádějí tři kritická hlediska: postavení hlavní teze vůči vedlejším tezím; rozčlenění obsahu podle historického,

29 Srovnej Aristotelés (2010, s. 33). 
konceptuálního, či logického principu; rétorická výstavba. ${ }^{30}$ Popíši zde klipy pouze z posledního uvedeného hlediska, tedy z hlediska pořadí, $\mathrm{v}$ jakém jsou jednotlivé části $\mathrm{v}$ projevu vyjádřeny. Tradiční rétorická kritika při strukturálním popisu obvykle využivá aristotelské čtyřdílné členění řeči ${ }^{31}$, nebo šestidílné členění latinské rétoriky ${ }^{32}$; protože chci upozornit na strukturální odlišnost klipů na rovině podpora/vyvrácení, popíši jejich rétorickou skladbu podrobněji pomocí šesti podcelků:

Úvod [0:00-0:25 (TGS i PB)]

V obou klipech obsahuje stejné kroky: začínají otázkou, pokračují odpovědí na tuto otázku a končí představením mluvčích. Smyslem úvodu je informovat publikum o cíli či obsahu diskurzu, získat jeho pozornost a motivovat ho k udržení pozornosti - klipy toho dosahují dramaticky formulovaným dotazem.

\section{Vyličení tématu [0:26-1:20 (TGS); 0:26-1:52 (PB)]}

Publiku je předložen širší kontext situace, popis problému, jeho povaha, původ, důležité okolnosti. V př́padě TGS jde o tvrzení, že za případný volební neúspěch budou moci staří Židé z Floridy, kteří nevolili Obamu. Hlasy starých Židů z Floridy jsou přitom významné, což je podpořeno odkazem na výsledek starší prezidentské volby. PB začíná podobně: za případný volební neúspěch budou moci staří lidé z venkova, kteří volili levici. Pokračuje se však jiným směrem; následuje totiž vysvětlení, proč staří lidé volí levici, ilustrované odkazem na chyby bývalého komunistického režimu. Rozdíl mezi TGS a PB je v pozornosti, jaká je věnována diagnóze a hodnocení problému. TGS neříká, proč lidé volí tak a tak, negativní hodnocení nevoličů Obamy je vyjádřeno nepřímo. PB věnuje hodně místa vysvětlování voličské psychologie, srovnatelné množství času pak tráví kritikou takto motivované volby. Vylíčení tématu v obou případech končí výslovnou formulací cíle: mluvčí chtějí přesvědčit publikum, aby přesvědčilo seniory.

30 Srovnej Thonssen \& Baird (1948, s. 393).

31 Srovnej Aristotelés (2010, s. 195).

32 Srovnej Rhetorica ad Herennium (1954, s. 9). 


\section{Rozvržení tématu}

Představení struktury řeči není v klipech explicitně př́tomné. Je to pochopitelné, nebot projevy jsou krátké a přímočaré a divák se v nich orientuje dostatečně i bez předběžného rozvrhu. Oba klipy navíc využívají pro významné strukturální předěly hudební vodítka, TGS dále člení projev pomocí titulků a názvů kapitol.

Podpora [1:21-3:34 (TGS); 1:53-3:30 (PB)]

TGS obsahuje tři obecné přesvědčovací linie:

1. Staří Židé a mladí černoši jsou si podobní. [1:35]

2. Obamova politika je ke starším Židům vstřícná. [2:55]

3. Za správnou volbu dostanou senioři odměnu. [3:25]

PB obsahuje dvě obecné přesvědčovací linie:

1. Levice je špatná. [2:05]

2. Za správnou volbu dostanou senioři odměnu. [3:25]

Všimněme si, že ani v jednom případě nejsou předkládané důvody spojené s explicitně tvrzeným cílem. Nepřesvědčují se mladí lidé, aby jeli přemlouvat staré; předkládají se zde důvody, jakými by mladí měli přemlouvat staré. Ústřední část diskurzu je tak vlastně rétorickou instruktáží, průpravou v přesvědčování, nikoli přesvědčováním o ústřední tezi. Hledáme-li důvody pro hlavní tezi, že mladí lidé by měli podniknout cestu na Floridu či na venkov, musíme hledat v úvodu a závěru klipu. Podstatné je, že podpora je mnohem bohatěji vyjádřena v TGS. Zdůvodňování, proč by staří Židé měli volit Obamu, je věnován velký prostor, nabízené důvody jsou pestré. U PB je patrné, že tato část vlastně není zase tak důležitá; mnohem důležitější je zde totiž následující funkční celek.

Vyvrácení [2:18-2:52 (TGS); 2:08-3:14 (PB)]

V obou klipech je zpochybnění argumentů protistrany poněkud netypicky vloženo dovnitř podpory, jmenovitě vždy mezi linie (1) a (2). Kritická pozornost je pokaždé věnována jedné námitce, její vyvrácení je však vnitřně ko- 
šaté. TGS se soustředí na námitku, že Obama má muslimsky znějící jméno. Zpochybnění této námitky pak probíhá pomocí následujících důvodů:

a) Židé mívají podivně znějící jména. [2:35]

b) Etymologie jména je židovská. [2:38]

c) Protikandidátovo jméno má horší etymologii. [2:45]

PB se věnuje námitce, že levicová vláda by pro mladé byla výhodnější. Odmítnutí této námitky se vede následujícími prostředky:

a) Levicová vláda by mladé zadlužila. [2:25]

b) Zrušení poplatků ve zdravotnictví je sobecké. [2:35]

c) Levice nechce provést důchodovou reformu. [2:45]

d) Levice nechce provést školskou reformu. [3:05]

Pro PB je vyvrácení nejdůležitější rétorickou složkou. Zatímco v TGS trvá vypořádání se s námitkou přibližně půl minuty, vyvrácení v PB je dvojnásobně dlouhé. TGS se věnuje obavě seniorů a vyvrácení je doplňkem podpory; PB se věnuje obavě mladých a vyvrácení zastiňuje podporu.

Závěr [3:35-4:00 (TGS); 3:31-3:51 (PB)]

Zkoumané klipy pojímají závěry odlišně. TGS rekapituluje důvody a snaží se v publiku vzbudit sympatie, nikoli však k samotné mluvčí, nýbrž k prezidentskému kandidátovi; plynule pak přechází k zopakování klíčové výzvy. Pozoruhodná je poslední věta klipu, která v publiku evokuje silnou náklonnost $k$ seniorům. PB uzavírá jinak. Mluvčí se snaží publikum motivovat k aktivitě odměnou, předkládají tedy další důvod pro hlavní tezi. Protože je ale zjevné, že nejde o vážně míněný důvod a slíbenou odměnu publikum stejně neobdrží, je zde cílem nejspíš pomocí odkazu na sdílené hodnoty vyvolat náklonnost publika $k$ mluvčím.

\section{Analýza sdělení}

Tradiční rétorická kritika je orientovaná na účinek; kritik má zhodnotit, do jaké míry se mluvčímu podařilo vzbudit v posluchačích náklonnost 
k předloženým myšlenkám. Z hlediska analýzy je tak pro tradiční rétorickou kritiku klíčová následující otázka: Jaké prostř̌edky zvolil mluvčí při adaptaci řeči danému publiku?

Rekapitulujme, že bezprostřední publika obou klipů a jejich explicitní cíle se zásadně neliší. Mladí lidé jsou oslovováni tak, aby se v nich posílila politická a morální zodpovědnost. $V$ obou případech má rovněž dojít k přesvědčování vzdáleného, seniorského publika, které je však v klipech konstruováno odlišně: TGS líčí vzdálené publikum se sympatiemi, PB $\mathrm{s}$ antipatiemi. V následující části svého textu budu sledovat způsoby, jimiž se mluvčí obou klipů snaží přesvědčovat. Bude mě zajímat adaptace řeči výše popsaným publikům, a to na půdorysu aristotelského rozdělení důkazů na osobnostní (etické), emocionální (patetické) a logické. ${ }^{33}$ Tradiční rétorická kritika převzala toto členění jakožto obecné analytické kategorie popisu a hodnocení persvazivních strategií v rámci invence ${ }^{34}$ a třebaže přiznává jisté prolínání těchto kategorií, přistupuje k nim jako k samostatným složkám přesvědčovacího procesu.

\section{Etické přesvědčování}

Přesvědčování pomocí osobních kvalit (etický důkaz), tedy postup, při kterém se mluvčí snaží zapůsobit na publikum intelektem, morálním charakterem či vstř́icností, ${ }^{35}$ lze podle Thonssena a Bairda ${ }^{36}$ bez nároku na úplnost popsat pomocí následujících taktik:
Intelekt
a. Mluvčí budí dojem, že spoléhá na ,zdravý rozum‘.
b. Jedná taktně a umírněně.
c. Projevuje dobrý vkus.
d. Odhaluje širokou obeznámenost s trendy.
e. Obratností projevu ukazuje svoji bystrost.

\footnotetext{
33 Srovnej Aristotelés (2010, s. 26-27).

34 Srovnej Thonssen \& Baird (1948, s. 331).

35 „Tolik jest totiž příčin, pro něž někomu věříme, nehledíme-li k důkazům. Jsou to rozumnost, ctnost a př́zeň." (Aristotelés 2010, s. 90).

36 Thonssen \& Baird (1948, s. 387).
} 


\section{Morální charakter}

f. Mluvčí spojí sebe či své sdělení s tím, co je dobré a vznešené.

g. Předloží umírněnou chválu sebe, svého klienta a jeho jednání.

h. Spojí protivníka nebo jeho jednání s tím, co není dobré.

i. Rozptýlí protivníkem dříve nastolený nepříznivý obraz sebe sama či svého jednání.

j. Využívá autority své osobní zkušenosti.

k. Vytváří dojem naprosté otevřenosti a upřímnosti.

\section{Vstř́cnost}

1. Mluvčí nechválí publikum ani př́liš málo, ani příliš mnoho.

m. Patřičně se identifikuje s posluchači a jejich problémy.

n. Postupuje př́močaře a cílevědomě.

o. Nezbytná vyvrácení předkládá taktně a uvážlivě.

p. Kompenzuje osobní zájem v dané věci.

q. Bez chvástání odhaluje své osobní epistemické kvality.

Při popisu adaptace přesvědčovacích prostředků v obou klipech začnu u rozdílných způsobů identifikace s posluchači (m). V TGS je vztah mluvčí k publiku dvouvrstvý. V první vrstvě se s publikem identifikuje prostřednictvím vzhledu, jazyka a gest. Mluvčí působí mladě, sportovně, bez uzardění používá slangové vulgarismy. Gestikulace je výrazná a energická, někdy až dětská, srovnej obrázek 2.

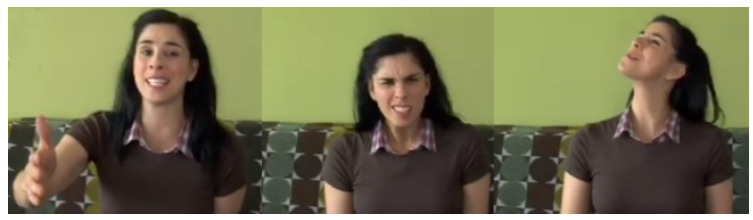

Obrázek 2

Ve druhé vrstvě se ale mluvčí od publika distancuje, a to zejména patronizujícím tónem řeči [1:03] a adresováním (,ger your fat jewish asses 
on a plane to Florida'). ${ }^{37}$ Silvermanová působí jako moderátor diskuse mezi mladými a starými či jako interpret, který tlumočí obavy starších lidí do jazyka mladších. Toto obecné zprostředkující postavení mluvčí k publiku je v TGS naznačeno v postavení mluvčí při srovnávání starší Židovky a mladého černocha [1:25]. Silvermanová zaujímá střední pozici, v níž se snaží zdơraznit podobnosti a strany propojit, a to dokonce názornými gesty [1:40]. Analogickou pozici mluvčí zaujímá ve vztahu k prvotnímu publiku a konstruovanému vzdálenému publiku: rozumí oběma stranám, snaží se je spojit a radí mladým, jak toho dosáhnout. V PB je situace jiná. Identifikace mluvčích s publikem je zřejmá a velmi silná. Nejde jen o věk, vzhled a jazyk, mluvčí se na několika místech s publikem výslovně ztotožňují, např. ,tak my je pak budeme do konce života splácet ${ }^{6}$ [2:28], ,dost sobecký rozhodnutí, který třeba mě poškodí‘ [2:36]. Na žádném místě se mluvčí z publika nevyčleňují; působí tak nikoli jako interpreti starší generace, nýbrž jako hlasy mladší generace.

Řadu postupů etického přesvědčování pochopitelně oba klipy sdílejí, o některých již byla řeč: mluvčí hned v úvodu rámují svá sdělení jako morální (f), používají jazykové prostředky, jež mají působit upřímně (k), jejich řeč má explicitně a jasně oslovit bezprostřední publikum (n). V obou klipech se mluvčí představují - což není z jejich strany pouhým projevem zdvořilosti, nýbrž paradoxně také projevem očekávání, že publikum jejich jména již předem zná a spojí si je se sdělením (j); neznámí mluvčí by zde svá jména neuváděli, nebyl by $\mathrm{k}$ tomu důvod. ${ }^{38}$

V některých ohledech se však klipy rozcházejí, například přicházejí s odlišně budovanou epistemickou autoritou (a). Naznačil jsem výše, jakou úlohu hraje v PB Jiří Mádl. Má ztělesňovat racionální hledisko akcentující férovost: na třech místech koriguje nevhodně úzký název klipu [0:20, 0:41, 3:49], opravuje nevhodné zobecnění [2:03] a ilustraci [1:51], komentuje argumentaci vzdáleného publika [2:09].39 Jeho étos znalce

37 Odstup od publika měl být v původním návrhu kampaně ještě výraznější, nebot tvůrci nejprve oslovili v té době šedesátiletého židovského komika a producenta Larryho Davida, který však nabídku stát se tváří TGS odmítl.

38 Celebrity endorsement je o něco silnější v TGS, kde je jméno Sarah Silvermanové uvedeno přímo jako titulek uvnitř klipu [0:22].

39 Z tohoto hlediska je trochu matoucí humorná výměna v úvodu klipu [o:46], kde Mádl chápe položenou otázku př́liš omezeně a Issová mu ji musí vysvětlit. I s pomocí mimiky zde Mádl buduje divácké očekávání, že v klipu bude hrát roli jakéhosi omezeného mladšího bratra hlavní mluvčí 
je v klipu budován přednáškou s náležitou dikcí, mimikou a gestikulací [o:57], aby byl později využit k posílení argumentů týkajících se školného [2:56] a k vyvrácení protiargumentů [2:08]. Dostane-li šanci, přijímá výraz učitele a jeho gestikulace je střídmá, srovnej obrázek 3.

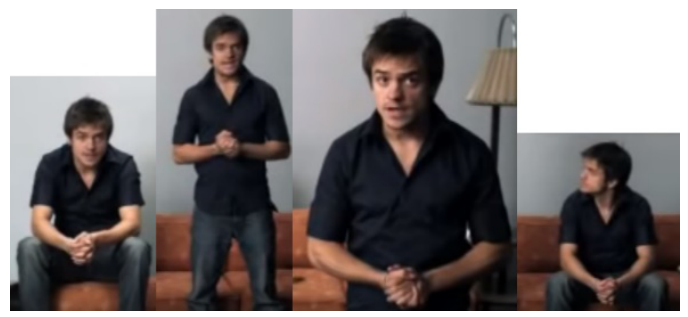

Obrázek 3

V TGS předkládá Silvermanová zcela jiný osobní obraz. Její mluvčí chce působit roztomile; nehovoří z pozice strohé intelektuální autority, nýbrž z pozice empatického, zábavného, živelného hostitele. Toto rozdílné budování důvěry nemá samo o sobě za cíl př́imé přesvědčování, je však významné kvůli směrování pozornosti publika. Signalizuje, jaký způsob přesvědčování je zde ten důležitý: zda se má publikum soustředit na seriózně předkládané důvody v $\mathrm{PB}$, nebo zda má spíše vstřebávat náladu TGS.

TGS rovněž využívá dílčích charakteristik slavnostní řeči a na jednom místě předkládá soustředěný přehled kladných vlastností (g) prezidentského kandidáta [3:35-3:48]; podobnou taktiku v PB nenajdeme. Co však najdeme v obou klipech, je negativní etické přesvědčování (h): TGS na jednom místě spojuje protikandidáta $\mathrm{s}$ pocitem znechucení [2:462:50] - PB věnuje velkou pozornost líčení nekompetentnosti [0:561:10] a sobectví [2:35-2:39] starých lidí, ztotožnění levice s totalitním komunismem [1:09-1:25] a zdůraznění jejího populismu [2:51-2:55]. Tento odlišný důraz na negativní přesvědčování je možná tím nejvýraznějším strategickým rozdílem: zatímco pro TGS je etické přesvědčování okrajovým postupem, pro PB je zpochybnění morálních a intelektuálních kvalit protistrany středobodem řeči.

- možná má jít o aluzi jeho známých rolí v populárních filmech pro mládež; téměř okamžitě však překvapí odbornou vsuvkou a stylizaci mentora pak již neopustí. 


\section{Patetické přesvědčování}

Tradiční rétorická kritika chápe emocionální přesvědčování jako druhotný persvazivní kanál. ${ }^{\circ 0}$ Nesnižuje vliv emocí na rozhodovací proces, ovšem zdůrazňuje jejich podřízenost logickému dokazování; rétorická kritika má zohledňovat především racionální rovinu přesvědčování; patetické přesvědčování je doplňkem. ${ }^{41}$ Domnívám se však, že emoce a způsoby, jakými jsou emoce vzbuzovány, jsou pro pochopení př́padných odlišností v persvazivních účincích obou klipů klíčové - a to jednoduše proto, že TGS využívá patos jako hlavní přesvědčovací prostředek. Emoce jsou zde důležitější než argumenty a mnoho logicky vypadajících argumentů je ve skutečnosti emocionálním apelem. Publikum je motivováno, stmelováno, usměrňováno především mimoracionálními prostředky.

Jaký je cíl TGS? Přimět publikum, aby vykonalo přesvědčovací cestu na Floridu. Proč se tento cíl jeví publiku jako lákavý? Protože je spojen s pocitem hanby. $\mathrm{V}$ úvodu klipu je ten, kdo neusiluje o změnu světa, označen nelichotivým př́zviskem ,douche nozzle'. Změna světa, jak se brzy ukáže, v tomto př́padě znamená změnu na pozici prezidenta, a je-li někdo v tomto směru nečinný, měl by se cítit zahanben. $\mathrm{V}$ závěru klipu je pocit hanby využit podruhé [3:48], když Silvermanová zmiňuje mizernou reputaci Američanů jakožto ,assholes of the Universe'. Publikum má cítit stud, jenž je pohne k cestě na Floridu a napravení reputace.

Obhajobou cíle se ale patetické přesvědčování v TGS nevyčerpává. Emocionálně nabité postupy najdeme vlastně ve všech částech klipu. Když mluvčí tvrdí, že cesta na Floridu je před nadcházející prezidentskou volbou žádoucí, podporuje to analogií s volbou z roku 2000, kdy byl demokratický kandidát Al Gore ,fucked by Florida' [1:08]. Expresivní vyjádření je provázeno vzteklou mimikou a držením těla. V samotném závěru klipu se zase mluvčí trochu nezúčastněně loučí slovy ,Love Nana' [3:55], jež mají v publiku utvrdit ústřední emoci TGS: shovívavou náklonnost.

40 „[M]ůžeme tvrdit, že důraz na emoce - patetické důkazy obecně - je třeba brát jako fakta či data rétoriky, nikoli však jako základní principy tohoto umění. S Aristotelem můžeme říci, že skutečný důkaz - posílení idejí logickými prostředky - je skutečným desideratem řeči.“ (Thonssen \& Baird 1948, s. 382).

41 Tamtéž. 
PB je z hlediska emocionálního přesvědčování mnohem střídmější. Cílem je přimět publikum, aby vykonalo přesvědčovací cestu na venkov. Motivací je zde pocit strachu, konkrétněji pocit ohrožení z návratu totalitních praktik. Značný prostor je proto v klipu věnován připomenutí politických procesů a nucené emigrace [1:06]. Všimněme si, že změna klíčové emoce klipu se odráží i ve změně slov v úvodu. Zatímco Silvermanová hovoří o ,změně světa', Issová hovoří o ,změně osudu týhle země‘; zatímco publikum TGS má cítit hanbu za současný stav a má tento stav změnit, publikum PB má cítit obavy z budoucího vývoje a má tomuto vývoji zamezit. Druhý a poslední př́ípad emocionálního přesvědčování publika PB je součástí analogie mezi levicí-rukou a levicí-stranou. Negativní hodnocení levice-ruky je zavedeno odkazem k hygienickým zvyklostem, líčeným jako nechutné. Pocit zhnusení má pak publikum přenést díky víceznačnosti výrazu ,levice‘ z jednoho analogu na druhý.

\section{Patos a vzdálené publikum}

Již byla řeč o tom, že oba zkoumané klipy jsou pozoruhodné tím, že jde o přesvědčování o přesvědčování. Mluvčí dávají rady publiku, jak úspěšně zapůsobit na seniory, přicházejí s persvazivními postupy určenými specifickému vzdálenému publiku. Podívejme se tedy, jakou roli hraje patos v těchto doporučovaných postupech. V TGS je emocionální působení př́tomno velmi výrazně: v odpovídajícím úseku TGS [1:21-3:35] lze rozpoznat hned několik linií přesvědčování vzdáleného publika, přičemž naprostá většina z nich obsahuje emocionální složku. Tyto linie můžeme chápat jako reakce na specifické obavy, které trápí vzdálené publikum:

\section{Obama je černoch.}

Mluvčí formuluje tezi, že staří Židé a mladí černoši jsou vnitřně stejní. Poukazuje na podobné stereotypní vlastnosti zástupců obou skupin a snaží se tak neutralizovat předsudky vzdáleného publika vůči černošskému kandidátovi. Jde o překonávání negativní emoce strachu vyvoláním pozitivního obrazu sounáležitosti, shody, spolupř́slušnosti. Při hledání podobností volí mluvčí nahodilé vlastnosti, které jsou pro publikum zjevně směšné. Cílem zde totiž není ustavení silné analogie mezi starými 
Židy a mladými černochy, jež by ospravedlnila nějaké další usuzování; cílem je zlidštění prezidentského kandidáta $\mathrm{v}$ očích vzdáleného publika. Z této perspektivy je nejsilnějším momentem vyvolání soucitu zmínkou o vysoké mortalitě [2:08-2:18]. Jde dokonce hned o dvojitý patetický účinek; vzdálené publikum má cítit soucit s Obamou, primární publikum má cítit soucit se vzdáleným publikem.

\section{Obama je muslim.}

Obavy vzdáleného publika jsou podle mluvčí vyvolány muslimsky znějícím jménem. Tyto obavy mají být rozptýleny několika cestami. Zaprvé, poukaz na skutečnost, že Barack je jméno hebrejského původu, má přispět k výše popsanému pocitu sounáležitosti mezi vzdáleným publikem a prezidentským kandidátem. Zadruhé, mluvčí připouští, že dojem vzdáleného publika ze jména Barack Hussein Obama je oprávněný a kvůli prostřední části má jméno zřetelně muslimský charakter. Pokračuje ovšem $\mathrm{s}$ tím, že vzdálené publikum by nemělo odsuzovat ,shitty name', jelikož židovská jména jsou sama podivná. $Z$ hlediska racionálního přesvědčování lze takový krok chápat jako tu quoque, tj. defektní osobní argumentaci umlčující protivníka poukazem na to, že on sám je nositelem kritizované vlastnosti. Z hlediska patetického přesvědčování jde ale jen o další příspěvek k posílení sounáležitosti mezi starými Židy a Obamou. Cílem zde není umlčení kritika poukazem na nesoulad mezi tím, co říká, co dělá či jaký je, nýbrž vyvolání soucitu s člověkem ve stejné situaci. Zatřetí, Obamovo jméno je lepší než jméno protikandidáta, nebot zatímco etymologie jména Barack je lichotivá, etymologie jména John (McCain) je urážlivá. Zde jde o jedno z mála útočných míst TGS a jde o místo, které je útočné nejvíce. Přesvědčování je založeno na vyvolání pocitu znechucení, odporu vůči vulgárním a expresivně vyjádřeným konotacím konkurentova jména.

\section{Obama není Žid.}

Jak již bylo řečeno, u vzdáleného publika je konstruována silná etnická př́islušnost. Pro seniory z Floridy je mimořádně důležité to, že jsou Židé; pro jejich volbu je vztah kandidáta $\mathrm{k}$ židovství zásadní. Mluvčí proto zmiňuje Obamovu zahraniční politiku, zejména vstřícný postoj 
k Izraeli. Očekává se, že publikum pochopí pozitivní zahraničně-politický postoj k Izraeli jako obecně pozitivní postoj k Židům, potažmo k americkým Židům. Patetické přesvědčování je přítomno až v navazující zmínce o Obamově kvalitním pečeném hovězím a ,obří obřízce‘ [3:14]. Podobně jako v předchozích liniích jde i zde o použití nahodilých, a tedy za daných okolností humorných vlastností, jež jsou spojeny s židovským stereotypem a jež mají posílit sounáležitost specifického vzdáleného publika s Obamou. Cílem tedy opět není předložení racionálního důvodu, nýbrž vzbuzení tmelící emoce.

\section{Voliči jsou staří.}

Drobnou zmínku o Obamově snaze ochránit sociální pojištění, jehož významnými př́ijemci jsou senioři [3:02], nelze považovat za emocionální přesvědčování. V TGS najdeme patos směřující ke staršímu publiku na jiném místě, a sice v již diskutované pasáži srovnávající staré Židy a mladé černochy. $V$ jednom okamžiku totiž mluvčí připisuje oběma stranám to, že jsou ,crazy about their grandkids' [1:47]. Taková charakteristika nedává smysl; neočekává se, že by mladí černoši měli vnoučata. Tento obsahově nesmyslný krok je však persvazivně výhodný ze dvou důvodů. Předně buduje pozitivní emocionální vazbu mezi publikem, vzdáleným publikem a Obamou. Mladé publikum má cítit, že je milováno svými prarodiči (a možná prostřednictvím asociace i Obamou), a má podobnou emocí oplácet. Vedle toho jde o př́ípravu pro následující výzvu k emocionálnímu přesvědčování:

„You don't have to use facts, use threats!“ [3:17]

Mluvčí výslovně instruuje publikum, aby přešlo od racionálního přesvědčování k emocionálnímu. Mladí lidé mají využít náklonnosti seniorů a slíbit jim za správnou volbu návštěvu navíc. Proč mluvčí hovoří o hrozbě, když jde zjevně o př́slib odměny a nikoli trestu? Hrozba je skryta v doplnění, že pokud senioři správně volit nebudou, tak ,let's just hope they stay healthy until next year'. Hrozba zde má podobu mementa mori; staří lidé si mají uvědomit svůj věk a zvážit, zda by jim nestálo za to vyměnit volební lístek za čas $\mathrm{s}$ vnoučaty. $Z$ tohoto hlediska jde vlastně 
o jakési emocionální pokračování předchozí linie: vzdálené publikum je staré a připomínka této skutečnosti na něj může mít přesvědčovací dopad.

Nelze jednoznačně odpovědět na otázku, zda jde o seriózní rétorické doporučení. Můžeme se ptát, zda by takto vybudovaná přesvědčovací strategie byla účinná; přesněji, zda si autoři klipu myslí, že by popsané využití odměny/hrozby mohlo být funkční. Osobně se domnívám, že ne, a že smyslem této instruktáže je ve skutečnosti něco jiného. Celou pasáž chápu jako emocionální přesvědčování mladého publika, nikoli jako návod k emocionálnímu přesvědčování vzdáleného publika. Mladí lidé mají díky zmínkám o lásce prarodičů $\mathrm{k}$ vnoučatům, vlivu vnoučat na prarodiče a jejich zdraví cítit účast, odpovědnost, obavy, soucit. Podle takového výkladu by tedy vlastně nešlo o hrozbu směřovanou seniorům, nýbrž o hrozbu ztráty směřovanou jejich vnoučatům.

Podívejme se na způsoby emocionálního přesvědčování vzdáleného publika v PB. Z hlediska patetického účinku je přesvědčování ploché a využita je vlastně jediná emoce: stud. Staří lidé, kteří budou volit levici, by se měli stydět, nebot’ jejich volba je sobecká. Tato negativní emoce pak vytváří obecný hodnotový rámec, uvnitř kterého se vede přesvědčování racionálními postupy. PB samozřejmě přebírá instruktáž o emocionálním přesvědčování. I zde mají mladí použít nátlak a slíbit starým lidem z venkova návštěvu navíc. Drobné změny ve slovech a přednesu však vyznění této pasáže mění: ,A když né, no tak doufejme, že budou ještě naživu, až příště přijedete.' [3:25] Nezúčastněné frázování doslovné hrozby provázené fotografí hrobu rozhodně žádnou sympatizující interpretaci neumožňuje. Memento mori je zde připomínkou slabosti starých; něčím, čemu se má mladé publikum vysmát. V PB navíc tato formulace následuje nedlouho po frázi ,zatímco voni si v klidu umřou', což cynické čtení mementa mori ještě zdůrazňuje.

Rozdílné zohlednění emocí je pro objasnění odlišného rétorického účinku obou klipů zásadní. U TGS jsou tmelící emoce sounáležitosti a soucitu hlavní přesvědčovací složkou. Mnoho předkládaných důvodů se z hlediska racionálního hodnocení jeví jako nesmysly; pokud je ovšem budeme chápat jako nástroje patetického přesvědčování, bude jejich účinnost nesporná. PB se naopak snaží přesvědčovat racionálními pro- 
středky. Taková volba je sama o sobě v pořádku, dokonce je dialekticky lepší, její provedení v PB ovšem není důsledné. Klip obsahuje patos, jmenovitě využívá pocitů nadřazenosti a pohrdání na straně mladého publika, pocitu studu na straně vzdáleného publika. Tyto negativní emoce jsou pak kvưli absenci jiných emocí obzvlášt patrné.

\section{Logické přesvědčování}

Stejně jako jsme se v př́padě etického i patetického přesvědčování ptali po prostředcích adaptace řeči publiku, musíme se i při tradiční rétorické analýze logického přesvědčování ptát, zda a jak mluvčí přizpůsobil výběr racionálních důkazů konkrétnímu publiku. Specializované nástroje argumentační analýzy, představené $\mathrm{v}$ dalších př́spěvcích, dokáží postupy racionálního přesvědčování zachytit pečlivěji. Nebudu se zde proto argumentům věnovat podrobně, popíši pouze v duchu neoaristotelské rétorické kritiky odlišnou topickou skladbu obou klipů.

Topiky jsou podle Aristotela jakési obecné vzorce podpory, argumentační strategie, tematicky či strukturálně vymezené rodiny možných důvodů..$^{22}$ Jde samožrejmě o velmi hrubý katalogizační prostředek, ovšem poměrně užitečný nástroj vyhledávání argumentů. ${ }^{43} \mathrm{~V}$ následující analýze budu pracovat s následující zjednodušenou klasifikací ${ }^{44}$ obecných topik:

Definiční:

Rod

Části

Srovnávací:
Podobnost
Odlišnost
Míra

42 Srovnej Aristotelés (2010, s. 143 a dále).

43 Aristotelés rozlišoval mezi obecnými a speciálními topikami; obecné lze použít ve všech promluvách, speciální topiky jsou vždy vztaženy k danému typu řeči, existují tedy zvláštní poradní, slavnostní i soudní zdůvodňovací strategie.

44 Jde o strukturu podle Corbett (1965, s. 87). Z klasifikace vypouštím epistemické topiky, které nejsou v této analýze využity. 
Relační:
Př́čina a účinek
Předchůdce a následek
Protiklad
Kontradikce

Nejprve budu rekonstruovat argumentaci TGS; ukáži jednotlivé linie racionálního přesvědčování a bude-li to možné, přiřadím je $\mathrm{k}$ odpovídajícím topikám. Argumentační strukturu TGS parafrázuji následovně:

1. Stařri Židé a mladí černoši jsou stejní.

2. Barack Obama má lepší zahraniční i sociální politiku než protikandidát John McCain.

3. Není třeba mít obavy z Obamova muslimsky znějícího jména.

3.1. ,Barack Hussein Obama‘ je stejně špatné jméno jako ,Manischewitz Guberman'.

3.2. ,Barack' je jméno hebrejského původu.

3.3.,Barack' znamená původně ,blesk'. ,John` znamená původně ,záchod‘ či ,zákazník prostitut$\mathrm{ky}^{6}$.

\section{Staří Židé a mladí černoši jsou stejní. (Podobnost)}

Výrazná přesvědčovací strategie zdůrazňuje shodné vlastnosti vzdáleného publika a prezidentského kandidáta. Jde o použití srovnávací topiky, kde mluvčí pomocí výčtu sdílených vlastností doufá v přenos pozitivního hodnocení z jednoho člena na druhý. Z hlediska kvality argumentu jde o defektní zdůvodňování a slabou analogii - v souvislosti s emocionálním přesvědčováním však již bylo řečeno, že analogie mezi starými Židy a mladými černochy je v TGS slabá záměrně. Mluvčí sice uvádí řadu shodných rysů, zohledňuje specifičnost vzdáleného publika a vytváří zdání racionálního porovnání, ovšem povrchnost a humornost zvolených vlastností jasně odhaluje mimo-racionální přesvědčovací strategii. 
2. Barack Obama má lepší zahraniční i sociální politiku než protikandidát John McCain. (Míra)

Opět je použita srovnávací topika, tentokrát jde ovšem o zdůraznění rozdílných kvalit kandidátů, respektive jejich politických programů. Z hlediska racionálního přesvědčování a rozhodování by mělo jít o nejvýznamnějšś argumentaci, nebot' očekáváme, že volba politického reprezentanta bude vedena především $\mathrm{s}$ ohledem $\mathrm{k}$ jeho politickým postojům - ovšem TGS jde proti takovému očekávání. Argumentace je nerozvinutá a omezuje se na prosté konstatování hodnotících premis. Nejenže se mluvčí nesnaží ukázat, proč je Obamova politika lepší, stručná argumentace je navíc ironicky ohraničena: srovnání je na jedné straně zařazeno mezi ,fun facts', na druhé straně graduje hodnocením hovězí pečeně [2:54-3:11].

\section{Není třeba mít obavy z Obamova muslimsky znějícího jména. (Rod)}

Jde o definiční topiku, která v rámci vyvrácení cílí na konkrétní obavu židovských seniorů z Obamova jména. Podstatou této topiky je zpřesnění významu používaných slov a precizování pracovních definic, v př́padě TGS jde o reklasifikaci jména $\mathrm{v}$ očích publika. Tento obecný záměr je dále vyjádřen třemi samostatnými, topicky rozmanitými argumentačními liniemi:

3.1. ,Barack Hussein Obama' je stejně špatné jméno jako,Manischewitz Guberman'. (Podobnost)

Opět je využita srovnávací topika, stejně jako v bodě 1 jde i zde o nalezení shodných vlastností Obamy a publika, tentokrát týkajících se jména. Výše již byla řeč o tom, že výsledný argument lze při odhlédnutí od jeho patetického rozměru interpretovat jako tu quoque, nyní si všimněme zacílení argumentu. Zjednodušený dialektický rámec refutatio zde vypadá tak, že protagonista (mluvčí) oponuje antagonistovi (vzdálenému publiku). Antagonista hájí tacitní stanovisko ,Obama bude nepřátelský k židům', které podporuje tacitní tezí o Obamově přízni k muslimům, jež je sama podpořena muslimsky znějícím jménem. Co dělá protagonista? Uvedenou sekvenci nevyvrací, nýbrž směřuje svou námitku k nesouvisející tezi ,Obamovo jméno je divné‘. $Z$ logického hlediska jde tedy o nerelevantní proti-argumentaci. 
Dovolím si zde ještě jednu spekulativnější poznámku. Předvedený manévr lze chápat také jako argumentační chybu vycházející z ekvivokace. Silvermanová totiž na jednom místě označuje Obamovo jméno za ,super fucking shitty name [2:28] a podobnost tak konstruuje díky ose ,Obamovo jméno zní muslimsky - ,Je to podělané jméno - „Židé také mají podělaná jména'. Takový přechod je ovšem založen na víceznačnosti hodnotícího výrazu ,shitty'. V př́ípadě Obamy je jméno ,shitty zhruba ve smyslu ,nevhodné pro oslovení židovských voličư', v př́ípadě Gubermana je prostě jen nesrozumitelné. Jinak řečeno, vzdálené publikum by souhlasilo s tím, že jméno Barack Hussein Obama je shitty', nebot jde o jméno evokující muslimy. Souhlasilo by nejspíš i s tím, že jméno Manishewitz Guberman je ,shitty', nebot' je složité a zní divně. $Z$ toho však neplyne, že by ,shitty“ označovalo sdílenou vlastnost obou jmen, kterou lze výše popsaný argument zaštítit.

\section{2. ,Barack' je jméno hebrejského původu. (Kontradikce)}

Zde se jedná o relační topiku, ve které poukazujeme na neudržitelnost dvou vzájemně se vylučujících tezí či využíváme opozitních termínů. V kontextu TGS jsou hebrejské kořeny muslimsky znějícího jména kontradiktorní proto, že vzdálené publikum, které se identifikuje jako židovské, nemůže mít zároveň obavy z židovského jména. Jde o působivý manévr, kdy mluvčí otáčí slabinu v sílu, muslimské vyznění přebíjí židovským původem. Z hlediska logického hodnocení však i tady platí, že taková proti-argumentace je nerelevantní. Důvod je zjevný: muslimské vyznění je způsobeno jménem Hussein, nikoli Barack; etymologický původ jména Barack tak nemá s diskutovanou tezí souvislost.

Všimněme si, že relevanci dané zmínky bychom mohli zachránit tehdy, pokud bychom odpovídající část argumentace rekonstruovali jako podporu, nikoli jako vyvrácení. Kdyby totiž byla ona fráze míněna jako samostatná podpora Obamovy kandidatury ve smyslu ,Židé by měli volit Baracka Obamu, nebot’ jméno Barack má židovské kořeny', pak by nebylo možné namítat, že jde o matoucí přesunutí pozornosti z problematického „Hussein“ na méně problematické ,Barack'. Proti takové vstřícnější interpretaci však hovoří zařazení klíčové fráze mezi ostatní způsoby, jimiž mají podle mluvčí mladí rozptýlit obavy starých z Obamova jmé- 
na. Kdyby zde skutečně mělo jít z ničeho nic o nezávislou podporu teze a nikoli o zpochybnění argumentu vưči této tezi, bylo by takové řazení zmatečné a jen obtížně dešifrovatelné.

\section{3. ,Barack' znamená pưvodně ,blesk'. ,John’ znamená pưvodně ,záchod”.} (Protiklad)

Jedná se o další obecnou relační topiku, kde poukazujeme na odlišnost stejného druhu, v našem případě etymologie křestních jmen. McCainovo jméno původně označuje něco odpudivého, Obamovo naopak něco pozitivního. Výše bylo zmíněno, že použití této srovnávací topiky je jediným silně konfrontačním místem TGS. To stále platí, ovšem podíváme-li se na topický výběr ve vyvrácení, uvidíme střet v každé linii: nejprve je konfrontována přitažlivost jména publikem, pak představa publika o původu jména, nakonec představa publika o významu jména. Kvalita argumentů z logického hlediska odpovídá kvalitě původní obavy z Obamova jména, ve všech případech je však vzdálené publikum zohledněno a navržená vyvrácení jsou mu v rámci jednotlivých topik přizpůsobena.

Podívejme se nyní na podobu racionálního přesvědčování v PB. Opět předložím nejprve rekonstrukci argumentace, poté přiřadím jednotlivé přesvědčovací linie k odpovídajícím topikám:

1. Komunisté špatně vládli a přinutili nejlepší lidi k emigraci.

2. Volba levice jde proti zájmům mladých.

2.1. Čekají nás dluhy, nízké důchody a nekvalitní školství.

2.2. Zrušení poplatků u lékaře by bylo sobecké.

2.3. Levici zajímají staří voliči, ne budoucnost mladých.

1. Komunisté špatně vládli a přinutili nejlepší lidi k emigraci. (Kontradikce/ Podobnost)

Topické zařazení této argumentační linie není jednoduché. A to proto, že není jasná teze, kterou má tato připomínka v úvodu vlastně podporovat. 
Do úvahy přicházejí dvě interpretace: (i) jde o podporu teze, že staří lidé z venkova jsou nekompetentními voliči; (ii) jde o podporu teze, že současná levice je špatná jako komunisté.

(ad i) Topika Kontradikce. Staří venkované si odporují v tom, když s nostalgií vzpomínají na radosti mládí a zároveň zapomínají na zvěrstva tehdejšího komunistického režimu. Jejich pamět je výběrová, ohraničená horizontem osobních radostí, jejich politická volba je nerozumná. $\mathrm{V}$ této interpretaci je argument namířen vůči vzdálenému publiku.

(ad ii) Topika Podobnost. Komunisté jsou levicovou stranou, na základě přihlášení se jiných stran k levici lze negativní hodnocení komunistů přenést i na tyto jiné levicové strany. $\mathrm{V}$ této interpretaci je argument namířen vůči levicovým stranám obecně. $Z$ logického hlediska by šlo nejspíš o tzv. asociační chybu, kdy jsou vlastnosti nositele, tj. komunistické strany, chybně připsány skupině, tj. levicovým stranám.

Nejpravděpodobněji jde o jakousi kombinaci obou výše popsaných topik. Sled řečnických otázek ,Ne, jak je možný, že tu levici volej? Copak voni zapomněli, jak to tady těch čtyřicet let, co byli komunisti u moci, vypadalo?‘ [0:50] publikum zásobuje dvěma podstatnými tezemi, první se týká kvalit starých venkovanů, druhá kvalit levicové vlády.

\section{Volba levice jde proti zájmům mladých. (Kontradikce)}

Vyvrácení je v PB namířeno vi̊či argumentu, že volba levice je výhodná pro mladé lidi. Mluvčí se snaží ukázat nesoulad mezi tezemi starých venkovanů, kteří na jedné straně tvrdí, že sledují zájmy mladých, na druhé straně ovšem volí stranu, která zájmy mladých ignoruje.

Zde narážíme na zásadní odlišnost $\mathrm{v}$ analyzovaných klipech. Na rozdíl od TGS totiž není v PB topický výběr přizpůsoben publiku, argumenty nezohledňují seniory. Všimněme si, jak je v úvodu konstruováno vzdálené publikum: má jít o staré rodinné příslušníky z venkova, kteří trpí selektivní pamětí, proto volí levici. Očekávali bychom, že vyvrácení bude na tyto charakteristiky cílit. Je-li podle klipu důvodem volby levice omezená pamět seniorů, úspěšná přesvědčovací strategie by se na ni měla zaměřit. Argumenty by např́lklad mohly poukazovat na to, že levice, na kterou staří tak rádi vzpomínají, je už dávno pryč. Mohly by nabízet jiné výskyty selektivní paměti a jejich selhání. Mohly by poukazovat na to, 
že vláda levice bude pro samotné seniory nepřínosná. Vyvrácení by se mohlo soustředit na tezi, že za komunistů bylo lépe. Místo toho si PB vybírá argumentaci, jejímiž aktéry jsou mladí a cílovou hodnotou je jejich prospěch.

Rovněž si všimněme, že v úvodu PB se sice poměrně důkladně konstruuje vzdálené publikum jako starší rodinní příslušníci z venkova, ovšem podpora a vyvrácení pak pracuje pouze $\mathrm{s}$ tím, že jde o rodinné příslušníky. Skutečnost, že jde o venkovské publikum, není zohledněna vůbec a v klipu by vlastně vůbec nemusela být; věk sice zohledněn je, ale uvidíme, že subverzivně. Vrat'me se k TGS, tam jsou v topickém výběru zohledněny všechny charakteristiky vzdáleného publika (věk, etnicita, rodina, lokalita) - topická volba v PB naproti tomu ukazuje, jak je zde vzdálené publikum zploštěno do jednorozměrného posluchače, který to $\mathrm{s}$ mladými myslí dobře, tečka. $\mathrm{V}$ žádném okamžiku PB nejsou senioři ničím víc, než instrumentem $\mathrm{k}$ dosažení výhod pro mladé.

Kontradiktorní postoj starých voličů se mluvčí PB snaží dále podpořit třemi argumentačními liniemi:

2.1. Čekají nás dluhy, nízké důchody a nekvalitní školství. (Předchůdce a následek)

Jde o relační topiku, která uvažuje volnější, nekauzální vztah mezi událostmi. Událost popsaná jako předchůdce povede k události popsané jako následek. $\mathrm{V}$ případě $\mathrm{PB}$ je tato topika vyjádřena v celé sadě dílčích argumentů popisujících negativní dopad př́ípadné výhry levice: klip zmiňuje růst zadlužení, neochotu levice provést důchodovou a školskou reformu.

\subsection{Zrušení poplatků u lékaře by bylo sobecké. (Kontradikce)}

Jde o tutéž topiku jako $\mathrm{v}$ bodu 2, dokonce je $\mathrm{v}$ jejím rámci argument i stejně konstruován. Staří lidé si odporují, když chtějí hájit zájmy mladých a zároveň odmítají zpoplatněnou lékařskou péči. Jde tak vlastně o opakování argumentačního postupu využitého na vyšší rovině, jen $\mathrm{s}$ tím rozdílem, že zde se nesoulad týká dílčí teze o zdravotnictví. Argument samotný je vyjádřen jen zkratkovitě, není patrné, jak zrušení poplatku ovlivní mladé. 


\subsection{Levici zajímají staří voliči, ne budoucnost mladých.}

Tato poslední podpůrná linie není ve striktním smyslu logická a už o ní byla zmínka $\mathrm{v}$ předchozí kapitole. $\mathrm{Z}$ pohledu tradiční kritiky by šlo nejspíše o formu etického přesvědčování, kde mluvčí poukazuje na špatný charakter či skrytou motivaci levicových stran. Snaží se zdůraznit jejich populistický, na současné staré voliče orientovaný program, který odmítá řešit budoucnost mladých.

Už základní topická klasifikace argumentů použitých v PB ukázala, že logické přesvědčování je zde charakteristické svojí konfliktností, přičemž tento konflikt se vede jinde, než bychom to čekali, tj. jinde než na ose levice-pravice. Stejné množství prostoru, jaký je věnován expozici argumentů, je totiž vždy věnován tomu, aby nějak oslabil pozici seniorů. Argumenty jsou prezentovány jako argumenty mladých proti starým:

(ad 2.1) „voni si v klidu umřou, tak my je pak budeme do konce života splácet“

(ad 2.2) „dost sobecký rozhodnutí, který třeba mě poškodi““

(ad 2.3) ,její voliči jsou starý dneska a ne za čtyřicet let“

Vyšší věk vzdáleného publika je v těchto poznámkách zohledněn, ovšem jak jsem naznačil výše, jen jako charakteristika, vioči které se mluvčí (a jejich prostřednictvím i publikum) negativně vymezují. Vyšší věk vzdáleného publika není podle nich něco, čemu by se mělo ,přemlouvání báby" přizpůsobit; je to něco, čemu se mladí mohou smát a na co mohou ukazovat prstem.

Topická rekonstrukce tak ukázala zásadní odlišnosti v argumentačních postupech zkoumaných klipů. Klipy kladou rozdílný důraz na logické přesvědčování: pro TGS jde o druhotnou persvazivní strategii, PB se naopak snaží přesvědčovat především touto cestou. Klipy se liší $\mathrm{v}$ přiměřenosti topického výběru zamýšlenému publiku: TGS nabízí postupy, které jsou orientované na seniory, $\mathrm{PB}$ ve všech př́padech cílí na mladé a senioři jsou instrumentální. Klipy se pak rozcházejí i v konstrukcích názorových kontroverzí: TGS tematizuje politický střet, PB střet mezigenerační. 


\section{Styl}

Součástí klasické rétorické analýzy je i rozbor použitých výrazových prostředků, tedy způsobu, jakým jsou přesvědčovací postupy vtěleny do jazyka. Taková analýza stylu pokrývá široké spektrum jevů, všímá si slovníku, délky vět, jejich gramatických a funkčních typů, rytmu, interpunkce, dalších způsobů členění řeči atp. O některých stylisticky významných jevech již byla řeč, zmiňoval jsem roli explicitního vulgarismu v úvodu TGS, související elipsu v PB, odlišný tón řeči u jednotlivých mluvčích, využití jidišismů. Bližší pozornost zde budu věnovat jen dílčím stylistickým prostředkům - vybraným řečovým figurám. Řečovými figurami míním různorodé variace výrazových prostředků, jejichž cílem je oživení projevu; jde tedy o postupy přesahující čistě informativní komunikační záměr. Existují nejrůznější klasifikace řečových figur ${ }^{45}$, zde budu pracovat $\mathrm{s}$ jednoduchým rozdělením figur na (syntaktická) schémata a (sémantické) tropy: schémata mění obvyklou podobu či uspořádání slov, tropy mění to, co slova obvykle označují. Zkoumané klipy využívají odlišných schémat a tropů; rozhodně tedy nelze tvrdit, že PB přebírá stylistické postupy TGS. Místo obvyklé komparace tak jen ukáži vybrané klíčové figury jednotlivých projevů.

Nejvýznamnějším a troufám si tvrdit, že i stylově nejpůsobivějším schématem TGS je klimax. Jde o seřazení slov či frází tak, že jejich závažnost roste. S tímto postupem se setkáme na několika místech klipu:

„They both love tracksuits. [...] All their friends are dying.“ [1:40-2:10]

„,... then a president named John, whose name means , toilet ${ }^{\star}$ or ,guy, who fucks hookers'، [2:48]

„He is honest and he is kind. And quite frankly, he is probably our last hope of ending this country's reputation as the assholes of the universe." [3:49]

45 Samotné označení ,figura bývá někdy vyhrazeno až pro podmnožinu stylově ozvláštňujících prostředků. V tomto smyslu používají daný termín i Thonssen a Baird, Srovnej Thonssen \& Baird (1948, s. 420 a následující). 
„You don't have to use facts, use threats.“ [3:17]

Pozoruhodné je, že ačkoli jde o oblíbený a velmi rozšiřrený stylistický nástroj, v PB tuto strukturu nenajdeme. Budování důrazu, stupňování $\mathrm{k}$ pointě, vrstvení důvodů a př́kladů není postup, který by byl v PB zřetelný a hierarchizace není využita. ${ }^{46}$ Zvláštní zřetel si zaslouží následující pasáž TGS:

„Barack Obama's foreign policy is much more stabilizing than John McCain's. [...] His brisket is beyond. It's beyond.“ [3:00-3:11]

Předně, jde o subverzivní využití klimaxu, jenž je zde zdrojem humoru. Nejvýznamnější důvod je zároveň ten nejpřízemnějšíí, což židovské publikum samozřejmě chápe jako vtip, ale zároveň je jím pozitivně ovlivněno. Vedle toho je však citace zajímavá i tím, že ilustruje výrazný stylistický postup TGS, a sice využití různých schémat opakování:

„His brisket is beyond. It’s beyond.“ [3:11]

„... to urge you, all of you..." $[1: 13]$

„I am gonna blame the Jews. I am.“ [0:32]

„,... to vote in Florida. And Florida vote can make or break an election.“ [0:59]

První dvě pasáže jsou př́íkladem epistrofy, ve třetí jde o anaforu, ve čtvrté o anadiplosi. Naproti tomu, v PB se schémata opakování vyskytují jen dvakrát:

„.. to jsou ty, který levici volej. To můžou bejt lidi z vaší rodiny. To může bejt vaše teta..." [0:35]

46 Poslední příklad je do PB převeden jako: „Když nezafunguje zdravej rozum, použijte nátlak.“ [3:15] Přitom by bylo snadné klimax zdůraznit např́klad formulací ,nemusíte zapůsobit rozumem, zapůsobte na city‘. 
„Hlavně když budete volit levici, tak si pak levice vytře zadek s váma.“ [2:04]

První citace využívá anaforu, druhá pasáž je komplexnější. Bereme-li v potaz pouze uvedené souvětí, jedná se o anadiplosi. Pokud však zohledníme i širší kontext, vidíme antimetabolu, tedy schéma opakování, ve kterém je pořádek slov v sousedících větách otočen:

\section{„... levou rukou si lidi všude na světě vytíraj zadek [...] když budete volit levici, tak si pak levice vytře zadek s váma“}

A konečně, v dané pasáži najdeme i tropus, konkrétně metaforu založenou na víceznačnosti výrazu ,vytřít zadek', jenž je poprvé užit v doslovném, podruhé $v$ přeneseném významu. $Z$ hlediska stylu je tato pasáž velmi zdařilým místem $\mathrm{PB}$, které se vymyká svojí rafinovanou konstrukcí jinak fádnímu okolí.

Obecněji lze rozdíl ve stylech zkoumaných klipů popsat jako zásadně odlišný důraz na důraz. Pro TGS je zdůraznění naprosto základním stylovým nástrojem. Rozhodně není prítomen pouze ve výběru srovnávacích schémat využívajících hierarchizace a opakování, důrazu je přizpůsobeno naprosto vše. Výrazná gestikulace, změny v intonaci a rytmice řeči, změny záběru kamery, hudba a vhodně umístěné pomlky. Srovnejme hudební podkres TGS, jenž se mění s ohledem na smysl sdělení a př́ihodně graduje [např. 1:36] s monotónním jazzovým klokotem $\mathrm{PB}$, který nereaguje na to, co se v klipu říká [např. 1:52]. PB proto ve srovnání s TGS působí jako uspěchaný, a tudíž nedostatečně intenzivní apel. Martha Issová se sice výraznou deklamací snaží projev zdůraznit, ale protože to dělá téměř u každé věty a hudba ji nijak nepodporuje, její řeč brzy po úvodní větě ztratí naléhavost.

Pro PB je totiž hlavním stylotvorným prostředkem ironie. Klip záměrně vysílá protichůdné signály, jejichž cílem ale není publikum zmást, nýbrž stmelit zaujetím reflektovaného odstupu. Tato strategie bude dobře patrná, srovnáme-li v klipech odlišně využité ilustrace. V TGS všechny obrázky dokumentují řečené: lidé, o které nám má jít, jsou hezcí; Židé jsou stereotypně metonymicky zastoupeni nosem; cesta je prostě cestou, 
toaleta toaletou, prostitutka prostitutkou atd. V PB jdou obrázky proti sdělení: lidé, o které nám má jít, jsou škaredí; staří jsou zastoupeni zubní protézou a ne třeba hůlkou; cestu ilustruje havárie vlaku; nejlepšími studenty v zahraničí jsou delikventi Mrázek a Krejčíř; milující prarodiče reprezentuje zvrhlík Fritzl. Očekává se, že publikum takové pomrknutí zachytí a bude jím v jistém smyslu uchlácholeno. Mluvčí celkem rozumně předpokládají, že přímá persvaze by na mladé tuzemské publikum příliš nepůsobila. Proto publiku předkládají momenty, ve kterých může od přesvědčovacího procesu odstoupit, aniž by se mu však vzdálilo př́íliš; publikum si tak zachovává svoji iluzi kritičnosti. Dodejme, že TGS dosahuje stejného účinku humorem, nejčastěji budovaným právě nad schématem klimaxu. Odstupu, nadechnutí se publika po intenzivním persvazivním úseku, dociluje ztřeštěným příkladem, vulgarismem, pomlkou. $\mathrm{Z}$ tohoto hlediska nenajdeme v klipech názornější místo než memento mori [3:30-3:35 (TGS); 3:25-3:30 (PB)]. TGS buduje důraz skvělou modulací hlasu Silvermanové a hudební pauzou, PB buduje ironii absencí modulace hlasu Issové, radostným zvoněním a obrázkem hrobu, srovnej obrázek 4 .

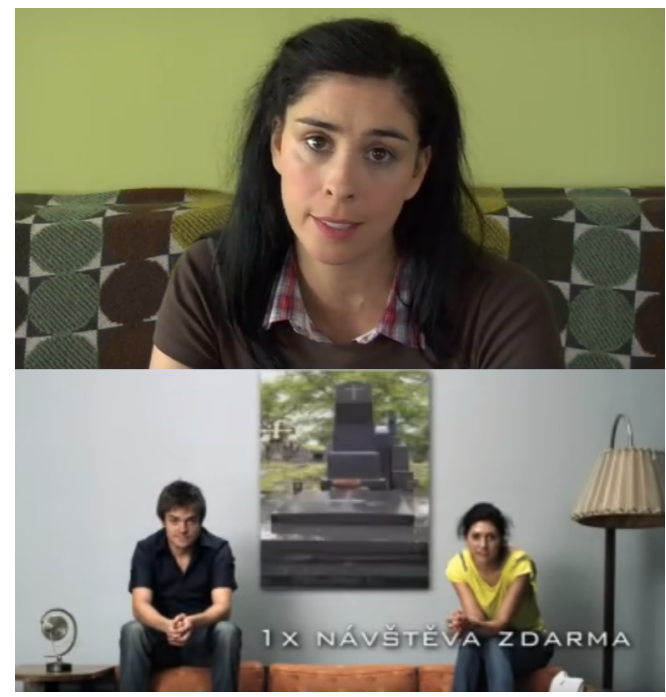

Obrázek 4 
Ironii najdeme v PB na mnoha místech, následující dva případy však překračují obvyklý kontrast slova a průvodní ilustrace: (1) Ironie vůči tónu. Psal jsem již o tom, že v úvodu PB je strategicky vynechán vulgarismus, sprosté slovo se nevyskytuje nikde v klipu. V určitém okamžiku je však obrazový doprovod velmi explicitní a vulgarismus je díky opakování „Kunderu... Milana Kunderu“ sice stále nevyjádřený, ale téměř hmatatelný [1:26]. Jakkoli je tato verbální hra př́izemní, její účel je pochopitelný - jde o signál publiku, že mluvčí s ním sdílí výrazy i konotace, byt' klip samotný vulgární jazyk nevyužívá; ironie je tak součástí etického přesvědčování. Stejně je tomu i v druhém případě: (2) Ironie vůči cíli. V závěru PB slibují mluvčí publiku odměnu. Tato odměna však není $\mathrm{v}$ žádném smyslu přiměřená závažnosti pohnutky představené $\mathrm{v}$ úvodu, ani vážně míněným přesvědčovacím postupům ve vyvrácení. Mluvčí slíbením odměny i její podobou zaujímají odstup od účelu klipu. Změna světa je nic ve srovnání s kvalitním antisystémovým pornem. Mluvčí tak v závěru ironizují politické angažmá mladých i sebe samotných. Účel je stejný jako kdykoli předtím, tj. identifikace s publikem, budování soudržnosti skrze odstup a zdání kritického nadhledu.

\section{Shrnutí}

Přemluv bábu je poměrně těsným převedením The Great Schlep do českého prostředí. Pod stejnou slupkou humorně laděné výzvy mladým se však skrývají odlišné přesvědčovací strategie. $Z$ celé řady identifikovaných rozdílů považuji za rétoricky nejvýznamnější tyto:

- Jiná konstrukce vzdáleného publika: TGS líčí seniory shovívavě a láskyplně, $\mathrm{PB} \mathrm{s}$ despektem.

- Jiné situování mluvčího: V TGS hraje mluvčí roli nestranného moderátora, překladatele mezi mladým a starým publikem; mluvčí v PB se ztotožňují s mladým publikem.

- Jiná struktura přesvědčování: TGS věnuje srovnatelný prostor podpůrné i kritické argumentaci; v PB se podpůrná argumentace vlastně nevyskytuje, ohniskem je kritika argumentů protistrany. 
- Jiné přesvědčovací prostředky: TGS klade důraz na emocionální přesvědčování, PB na logické přesvědčování; TGS sleduje perspektivu a zájmy seniorů, PB sleduje perspektivu a zájmy mladého publika; TGS buduje argumenty, pro staré, PB buduje argumenty ,proti starým‘.

- Jiný styl: TGS volí přímočaré konstrukce s výrazným opakováním a zdůrazňováním, jeho cílem je srozumitelnost, humor je vytvářen uvolněním rostoucího napětí; PB se téměř vyhýbá zdůrazňování, cílem je nadhled, humor je vytvářen ironií.

Přemluv bábu je vlastně jakousi permutací The Great Schlep. Téměř to vypadá, jako by si domácí tvůrci při sledování TGS dělali seznam použitých motivi̊, slov a obrázků, jenže než je stihli použít, většina z nich se jim pomíchala. V obou klipech se tak vyskytuje stereotyp (zahnutý nos vs. zubní protéza), lokalita (Florida vs. venkov), vulgární konotace vlastního jména (McCain vs. Kundera), toaleta (budka vs. vytírání zadku), explicitní obrázek (ňadra vs. vulva), portrét politika (Obama vs. Klaus), ovšem většina těchto motivů je v PB vlastně zbytečných.

Tou skutečně důležitou rétorickou změnou PB oproti TGS ovšem není permutace na úrovni motivi̊, nýbrž permutace na úrovni struktury. TGS je vybudován na přesvědčovacím půdorysu asociace skrze disociaci. Jeho cílem je spojení prezidentského kandidáta se starými Židy. Toho chce dosáhnout tím, že rozpojí Obamovo jméno s muslimy. PB je naopak vybudován na půdorysu disociace skrze asociaci. Cílem je rozpojení levice a mladých lidí. Toho chce dosáhnout tím, že spojí staré lidi se sobectvím. Argumentaci PB lze interpretovat následovně: ,Levici volí staří lidé, jejich motivy jsou ale sobecké. Mladí nejsou a nechtějí být jako staří, tudíž by mladí měli volit pravici.' Podle této interpretace je skutečným cílem Přemluv bábu přemlouvání mladých. Na rozdíl od TGS nejde o to, aby někdo někam skutečně odjel agitovat; jde o to, aby oni sami volili pravici. Tomuto ultimátnímu cíli je pak přizpůsobena strategická volba přesvědčovacích prostředků: voliči levice jsou líčeni jako staří, škaredí, hloupí, sobečtí, prostě jako skupina, vioči které se mladí voliči negativně vymezují. 
Oba klipy chtějí přmět své publikum k politicky motivovanému jednání. TGS hodlá aktivizovat staré voliče tak, že se jejich obavy pokusí rozptýlit mladí lidé. $\mathrm{PB}$ chce aktivizovat mladé voliče tak, že jim předloží některé argumenty vůči levici a zasměje se starým lidem. Režisér Petr Zelenka označil za hlavní poselství svého klipu to, že ,mladý lidi by se měli trochu víc zajímat o politiku ${ }^{67}$. Jakkoli chvályhodně tato myšlenka zní, kdybyste věděli, že můžete změnit osud týhle země tím, že přesvědčíte mladé, aby opovrhovali svými prarodiči, udělali byste to?

\section{Literatura}

Aristotelés (2010): Rétorika. Český překlad (A. Kř̌ž), Rezek, Praha. Arnold, C. C. (1959): „Rhetoric in America Since 1900.“ In Reestablishing the speech profession. The first fifty xears, eds. R. T. Oliver \& M. G. Bauer, Mineola: Speech Association of the Eastern States, 1959, s. 3-7.

Berger, V., Piroch, J. \& Bumba, J. (2010): „Webová agitka ,Přemluv bábu' vyvolává bouřlivé reakce." In iRozhlas [online]. 26. 4. 2010 [cit. 8. 11. 2018]. Dostupné z: https://www.irozhlas.cz/ zpravy-domov/webova-agitka-premluv-babu-vyvolava-bourlivereakce_201004261916_jpiroch.

Black, E. (1965): Rhetorical Criticism: A Study in Method. Macmillan, New York.

Nichols, M. H., ed. (1955): A History and Criticism of American Public Address, volume 3. Longmans, New York.

Bryant, D. C., ed. (1958): The Rhetorical Idiom. Essays in Rhetoric, Oratory, Language, and Drama. Cornell University Press, Ithaca.

Campbell, K. K. (1972): „The Forum: ,Conventional Wisdom Tradition Form': A Rejoinder." Quarterly Journal of Speech 58 (4): $451-456$.

Corbett, E. P. J. (1965): Classical Rhetoric for the Modern Student. Oxford University Press, New York.

47 ČT24 (2010, 3:10). 
ČT24. (2010): „Mádl s Issovou v klipu nabádají: Přemluv bábu a dědu, at nevolí levici!" In ČT24 [online]. Aktualiz. 23. 4. 2010 [cit. 8. 11. 2018]. Dostupné z: https://ct24.ceskatelevize.cz/ domaci/1340485-madl-s-issovou-v-klipu-nabadaji-premluvbabu-a-dedu-nevoli-levici.

Ehninger, D. (1965): „Rhetoric and the Critic.“ Western Speech 29 (Fall): 227-231.

Foss, S. K. (1989): Rhetorical Criticism: Exploration and Practice. Waveland Press, Long Grove.

Hendrix, J. A. (1968): „In Defense of Neo-Aristotelian Rhetorical Criticism." Western Speech 32 (4): 246-52.

Hill, F. (2009): „The „Traditional“ Perspective.“ In Rhetorical

Criticism. Perspectives in Action, ed. J. A. Kuypers, Lexington Books, Lanham, 2009, s. 39-61.

Issová, M., Mádl, J., \& Zelenka, P. (2010): „Přemluv bábu.“ In Youtube [online]. 22. 4. 2010 [cit. 8. 11. 2018]. Dostupné z: https://www. youtube.com/watch?v=MLfFhdcXJhA.

Klyn, M. (1968): „Toward a Pluralistic Rhetorical Criticism.“ In Essays on Rhetorical Criticism, ed. T. R. Nilsen, Random House, New York, 1968, s. 146-157.

Rhetorica ad Herennium. Angl. překlad (H. Caplan, 1954), Harvard University Press, Cambridge.

Sheskin, I. \& Dashefsky, A. (2010): Jewish Population in The United States. University of Connecticut, Storrs.

Silverman, S. (2008): „The Great Schlep.“ In Youtube [online]. 25. 9. 2008 [cit. 8. 11. 2018]. Dostupné z: https://www.youtube.com/ watch?v=AgHHX9R4Qtk.

STEM (2010): „Stranické preference - květen 2010.“ In STEM [online].

17. 5. 2010 [cit. 8. 11. 2018]. Dostupné z: https://www.stem.cz/ stranicke-preference-kveten-2010/.

Stewart, Ch. J. (1973): „Historical Survey Rhetorical Criticism in Twentieth Century America." In Explorations in Rhetorical Criticism, ed. G. P. Mohrmann, Penn State University Press, University Park, 1973, s. 1-31. 
Tate, N. (2012): „Jewish voters: By the numbers.“ In Reuters [online]. 24. 6. 2012 [cit. 8. 11. 2018]. Dostupné z: https://www. reuters.com/article/us-usa-campaign-jewish-vote-numbersidUSBRE86No5Z20120724.

Thonssen, L. \& Baird, A. C. (1948): Speech Criticism. The Development of Standards for Rhetorical Appraisal. The Ronald Press Company, New York.

Wichelns, H. A. (1925): „The Literary Criticisms of Oratory.“ In Studies in Rhetoric and Public Speaking in Honor of James A. Winans, ed. A. M. Drummond, Century, New York, 1925, s. 181-216.

\begin{abstract}
Same Different: a Traditional Rhetorical Comparative Analysis

The text compares the persuasive strategies used in similar political videos, The Great Schlep (2008) and Přemluv bábu (Convince your grandma, 2010). It shows that even though Přemluv bábu does not differ from its American original in the overall structure, the declared goal or the theme, it moves away from the original clip in other persuasively important aspects. The differences are especially evident in a construction of audience, the role of the speaker, and in the topical choice expressed by particular stylistic instruments.
\end{abstract}

Key words: rhetoric, neo-aristotelianism, Convince your grandma, The Great Schlep, comparison

Picha, M. (2018): „Když dva dělají totéž: srovnávací tradiční rétorická analýza.“ Filosofie dnes 10(2): 18-59. Dostupné z www.filosofiednes.ff.uhk.cz 